\title{
Risk Adjustment of Capitation Payment System: What Can Indonesia Adopt from other Countries?
}

\author{
Sistem Pembayaran Kapitasi Berbasis Penyesuaian Risiko: \\ Apa yang dapat Indonesia Adopsi dari Negara lain?
}

\author{
Asri Hikmatuz Zahroh', Rizki Asriani Putri', Latanza Shima ${ }^{1}$, Erdayani', \\ Rira Martaliza", Tri Priyo Anggoro, Wulansari \\ ${ }^{1}$ Fakultas Kesehatan Masyarakat, Universitas Indonesia, Depok, Indonesia \\ Korespondensi: Asri Hikmatuz Zahroh \\ e-mail:asri.hzO5@gmail.com
}

\begin{abstract}
Capitation calculation in Indonesia is not adjusted by individual and aggregate risk. Without risk adjustment, capitation rates are likely to overpay or underpay primary care. This study aimed to review risk-adjusted capitation payment in other countries for evaluation of capitation payment system in Indonesia. The conduct and reporting of this systematic review followed the recommendations of the Preferred Reporting Items for Systematic Reviews and Meta-Analyses (PRISMA). This study used comprehensive electronic search in five databases: Pubmed, Proquest, Scopus, PMC, and EBSCOHost. Search results from five databases in April 2018, yielded a total 19 titles that will continue to review the full article and at the end, 4 articles included for systematic review. Based on risk adjustment of capitation payment system in UK, USA, Canada and Sweden, Indonesia may initiate the use of risk adjustment based on the distribution of age and sex. Then Indonesia can develop risk adjustment based on diagnosis and socioeconomic factors to create more fair and accurate capitation rates for primary care. Keywords: Risk adjustment; Capitation; Primary Care
\end{abstract}

\begin{abstract}
Abstrak
Perhitungan kapitasi di Indonesia belum disesuaikan berdasarkan risiko individu dan agregat. Tanpa penyesuaian risiko, rate kapitasi cenderung untuk membayar lebih atau kurang fasilitas kesehatan tingkat pertama. Studi ini bertujuan untuk meninjau sistem pembayaran kapitasi di negara lain sebagai dasar evaluasi untuk sistem pembayaran kapitasi di Indonesia Penyusunan systematic review ini menggunakan rekomendasi dari Preferred Reporting Items for Systematic Reviews and Meta-Analyses (PRISMA). Studi ini mengumpulkan artikel dari lima database yaitu: Pubmed, Proquest, Scopus, PMC, and EBSCOHost. Hasil pencarian dari lima database pada bulan April 2018, didapatkan 19 judul artikel yang akan dilanjutkan untuk ditinjau secara menyuluruh, dan akhirnya didapatkan 4 artikel yang akan diikutsertakan dalam systematic review. Berdasarkan penyesuaian risiko sistem pembayaran kapitasi di UK, USA, Canada dan Swedia, Indonesia dapat memulai sistem pembayaran kapitasi berdasarkan penyesuiaan distribusi umur dan jenis kelamin. Selanjutnya Indonesia dapat mengembangkan sistem pembayaran kapitasi berdasarkan diagnosis dan sosioekonomi untuk menciptakan rate kapitasi yang lebih adil dan akurat untuk fasilitas kesehatan tingkat pertama.

Keywords: Penyesuaian risiko; Kapitasi; Pelayanan primer
\end{abstract}

\section{Introduction}

Capitation is a prospective unit of payment per patient, per month or year, in which a payer makes a fixed payment for a defined set of services, regardless of the quantity of services actually provided (Telykov, 2001). With this payment system, service providers will be aware of the risks and consequences as they perform services beyond what has been agreed. Capitation has three crucial elements: money follows the patient, payment of health services is paid at the earliest after determination of the number of patients registering, and recipients of payments are required to manage care effectively so that the expenditure is not greater than the payment received.

However, capitation payments are the result of mutual consent between the payer and the service provider. So that will be a question, how much should the capitation be agreed? In that context, it must consider the variation of possible health risks in the population. The many variations of health risks there need to be a risk grouping to determine the value of capitation. Dividing risk groups into small variations will burden service providers, as they relate to an uncertain population (unhealthy) but grouping risks into large variations will cost the payer's capitation because it requires a lot of responsibility and information to make frequent improvements in capitation quantities. Therefore, risk adjustment is better distinguished in a limited variety of groups. There are 
three recommendations for adjusting risk: socio-demographic (age, gender, place of residence, income, educational status, family size, employment status), past health expenditure and chronic sickness status.

The capitation payment system in Indonesia began with the introduction of the social insurance system in 2014. According to the Regulation of the Minister of Health of the Republic of Indonesia Number 69 Year 2013 concerning the Standard of Health Service Tariffs on First Level Health Facilities and Advanced Health Facilities in the Implementation of Health Insurance Program, capitation is payment amount per month paid in advance by BPJS Health to the First Level of Health Facility based on the number of participants registered without taking into account the type and amount of health services provided. This system applies to first-rate health facilities such as community health center, primary clinics, self-care physicians, and D grade hospitals (Minister of Health of the Republic, 2013).

The capitation rates in Indonesia have not been determined based on risk, the differentiation of the tariff only distinguished by the type of health facility and human resources. Without risk adjustment in determining the cost of health services, healthcare providers tend to be paid less or more than they do. This is the result of a review conducted by the Corruption Eradication Commission (KPK) which found that the mechanism of capitation made the funds entering the healthcare community in Indonesia has increased drastically and in excess of the healthcare needs of every year. If the excess funds accumulate every year, it will cause the accumulation of funds in a health facility, whereas a few healthcare workers can only raise funds (Nugraha, 2016). This paper aims to explore available risk adjustment methods and their determining factors which can be potentially applied to the capitation payment system in Indonesia.

\section{Method}

\section{Search Strategy}

The conduct and reporting of this systematic review followed the recommendations of the Preferred Reporting Items for Systematic Reviews and Meta-Analyses (PRISMA). Systematic Review with PRISMA method retrieved from online database Pubmed, Proquest, Scopus, and PMC. The search strategy used keywords: Risk adjustment AND Capitation AND Primary Care. An article must have written in English and published from 1998 until
2018. Mendeley was used to collect and manage all search result.

\section{Eligibility Criteria}

Transparent selection of papers for inclusion criteria in this study is using PICOS (Population, Intervention, Comparator, Outcome, Study Design) framework.

1. Population: Population of this study is primary care. IOM Committee defines primary care as the provision of integrated, accessible health care services by clinicians who are accountable for addressing a large majority of personal health care needs, developing a sustained partnership with patients, and practicing in the context of family and community (Institute of Medicine (US) Committee on the Future of Primary Care, 1996). Another definition of primary care in Indonesia is any activity undertaken by the government and/or public and private, to maintain and improve health and prevent and cure diseases and restore the health of individuals. Primary care includes health promotion efforts, disease prevention, outpatient treatment, inpatient treatment, restriction and disability recovery aimed at individuals (Ikatan Dokter Indonesia, 2014).

2. Intervention: Intervention in this research is capitation payment system. In capitation payment system, the provider is paid with a fixed rate in the fixed period and based on the number of individuals enrolled in a health facility. Articles that discuss other payment systems are not included in this study (Langenbrunner, Cashin dan Dougherty, 2009).

3. Comparator: There is no comparison in this research because this research focuses on one payment system that is capitation.

4. Outcome: An outcome of this research is risk adjustment method that used in every country. Capitation payments without the use of risk adjustment in the determination of tariff are not included in this study.

5. Study Design: The study design used is descriptive analytic which describes clearly the risk adjustment used in capitation payment system in a country along with its advantages and limitation.

\section{Study Selection}

Duplicated papers from five databases were deleted. We used Mendeley application for automatically deleted papers. Full papers which cannot be accessed, 
and not english language were excluded from this study. The title and abstract were screened by one author to exclude irrelevant papers. The full texts of remaining papers were screened by a remaining author with PICOS framework to meeting all inclusion criteria. All author discussed remaining papers which will be included in a systematic review.

\section{Result}

\section{Description of Search Result}

Search results from four databases in April 2018, yielded a total 883 articles using keywords. After removing the duplicate paper, not fully accessible and not English language, there are 841 papers included in the title and abstract screening. After the title and abstract screening obtained 19 titles that will continue to review the full article. Figure 1 presents the PRISMA flow diagram of study selection.

The results of the 19 articles review thorough- ly found that 15 articles were not included in the systematic review, one article did not specifically disclose the capitation payment system and Four articles only describes the proposed calculation of capitation in the future with risk adjustment. There were eight articles only describes the results of capitation payments but did not discuss in detail the results of risk adjustments in the capitation-funding system. Finally, two articles excluded from systematic review because of capitation system in those articles not specific for primary care.

\section{Risk Adjustment of Capitation Payment System United State}

United States use diagnosis, age, and gender as based on risk adjustment in capitation system. Advantages of this risk adjustment method are clinical data is well computerized, can predict the future use of health services, outputs from many risk adjustment programs can be collapsed into the fewer diagnostic

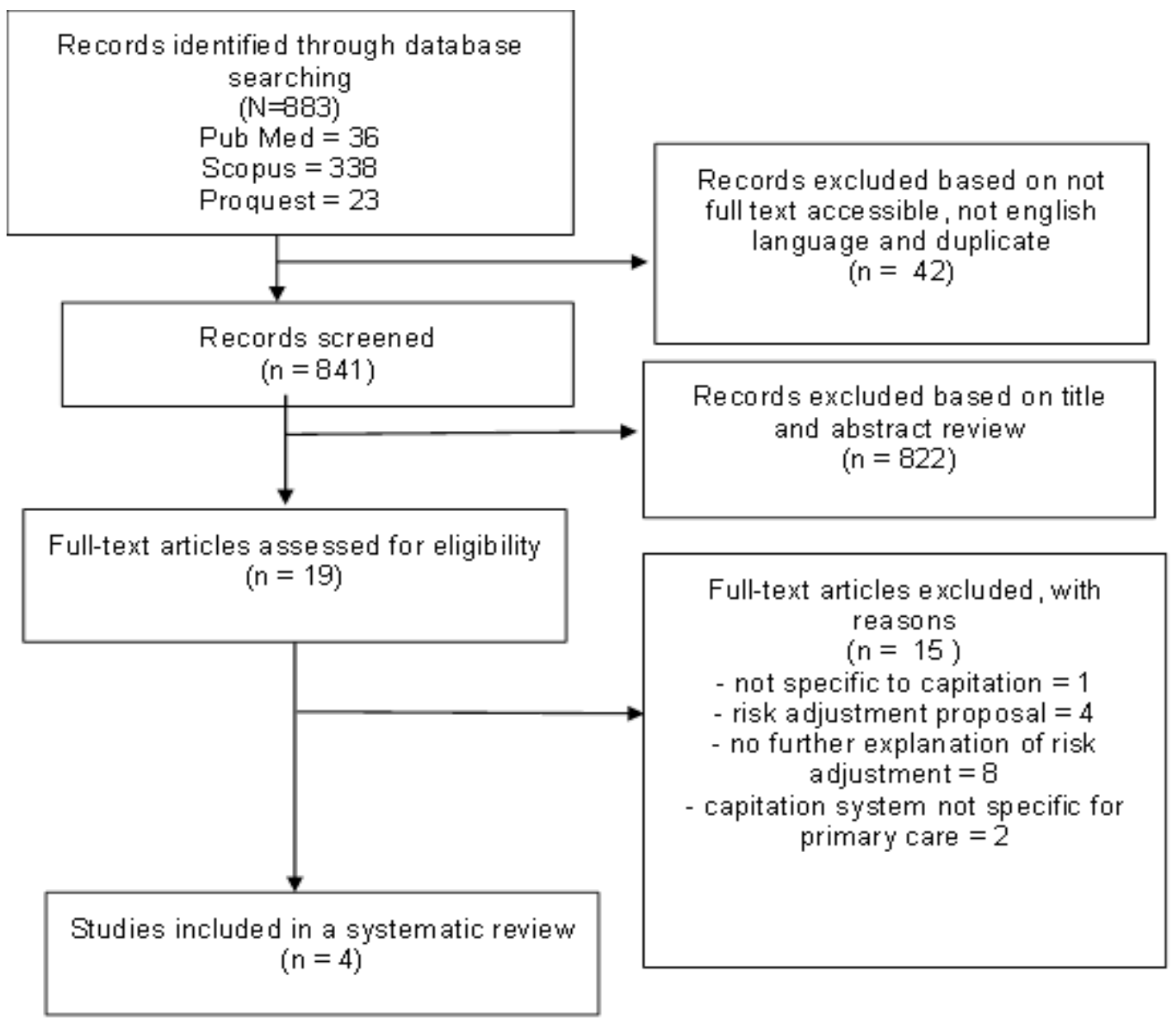

Figure 1. Pris ma Flow Diagram 
categories, and prevent primary care to compete in attracting healthy patients who are unlikely to take advantage of their health services. The limitations are frailty scores calculated after a bid has been submitted, but the changing nature of the marketplace and the different enrolment profile would not reflect its actual frailty score in the payment years (Majeed, Bindman dan Weiner, 2001).

\section{United Kingdom}

Risk adjustment in the United Kingdom uses age and sex along with standardized mortality rates and ecological measures of socioeconomic status. Advantages of this method are prevented doctors from taking on patients with complex health needs who would be expected to make high use of healthcare services. This method also will give primary care physicians fixed budgets determined by capitation formulae. Limitation of this method is lack of information about clinical factors and statistical models used to derive capitation formulae are complex, therefore most doctors or health service managers and are not well understood (Majeed, 2002)

\section{Sweden}

Sweden focused on the health care system for the equitable distribution of health services to the community. To improve equity for primary care, the Swedish government has implemented risk adjustments on capitation based on the Care Need Index (CNI) aimed at improving the capacity of primary care that having those with under-socioeconomic and poor demographic characteristics. CNI is an index that uses seven factors: children under five years old; people born outside the EU, Africa, Asia, or South America; elderly living alone; single parents with children less than seven years old; residents of 1 year or older who have just moved to the area; unemployed 16-64 years; and residents 25-64 years without education. The result of CNI implementation as a basis for adjusting capitation risk is the number of primary care in areas with high CNI and provides incentives for primary care in locating and creating the same supply of primary care (Anell, Dackehag dan Dietrichson, 2016).

\section{Canada}

Ontario Canada uses age and sex risk adjustment rates that reflect the health care needs of patients across all socioeconomic status by comparing the Ontario-based capitation compensation level index with the expected use of health care resources relative to socioeconomic status (SES). The danger of this payment structure is that it may be able to provide incentives for risk selection, usually referred to as cream-skimming, which is the practice of enrolling individuals who are expected to use below average levels of health care while discouraging or rejecting the expected individual enrolment using above-average levels of health care (Sibley dan Glazier, 2012)

\section{Discussion}

\section{Capitation Payment System in Indonesia}

One of the problems that has recently been highlighted is the issue of deposition of the capitation funds in primary care. The results of a study by Kompas Research and Development Division at the Supreme Audit Agency (BPK) found that all capitation funds in primary care throughout Indonesia reached Rp 3.02 trillion. Since the JKN program runs from 2014 to 2016, BPJS-Health has disbursed a capitation of Rp. 30.5 trillion to 2078 primary care consisting of primary care and Dental Clinic and Private Dental Clinic or TNI / POLRI. Approximately $74.4 \%$ or Rp.22.7 trillion of the total capitation fund is distributed to primary care (Susilo, 2018).

The problem is the calculation of capitation payment system is not based on risk adjustment related to service utilization. Thabrany says in the framework of behavioural model analysis, one of the main factors related to health service utilization is age predisposing factor (Thabrany, 2005). For example, the elderly will be more at risk of degenerative diseases with decreased physiological function, while the younger age group is more at risk for infection. From the results of research conducted by Kurnia and Nurwahyui concluded that the total acceptance of capitation funds will be more fairly if made per age for primary care, because the capitation fund received will be adjusted to the main factors of health service utilization, one of which is age. This is because capitation is based on the collection of risks from registered participants. Thus, health facility with more participants in elderly participants $(\geq 60$ years) or toddlers will get more capitation funds according to risk (Kurnia dan Nurwahyuni, 2015).

Besides the age factor, based on Ursila and Iljanto research about the description of health service utilization in primary care in JKN era, it is found that women use health service more than men, 63,7 and 36,3 respectively. This is due to different biological 
Table. 1 Studies included into analysis

\begin{tabular}{|c|c|c|c|c|c|c|c|c|}
\hline No & Author & Title & Year & Country & $\begin{array}{c}\text { Risk adjustment } \\
\text { method }\end{array}$ & Advantages & Limitation & Others \\
\hline \multirow[t]{2}{*}{1.} & $\begin{array}{l}\text { Aztem } \\
\text { Majeed, } \\
\text { Andrew B } \\
\text { Bindman, } \\
\text { Jonathan } \\
\text { Weiner }\end{array}$ & $\begin{array}{l}\text { Use of risk } \\
\text { adjustment in } \\
\text { setting budgets } \\
\text { and measuring } \\
\text { performance in } \\
\text { primary care I: }\end{array}$ & 2001 & UK & $\begin{array}{l}\text { Age and sex along } \\
\text { with standardized } \\
\text { mortality rates and } \\
\text { ecological measures of } \\
\text { socioeconomic status }\end{array}$ & & $\begin{array}{l}\text { Lack of information about } \\
\text { clinical factors, so they do not } \\
\text { take account of the prevalence or } \\
\text { severity of specific diseases. }\end{array}$ & $\begin{array}{l}\text { Prevent doctors from } \\
\text { taking on patients with } \\
\text { complex health needs who } \\
\text { would be expected to } \\
\text { make high use of } \\
\text { bealtheare services }\end{array}$ \\
\hline & School & bow it works & & US & $\begin{array}{l}\text { Medical bistory } \\
\text { (diagnonis), age, and } \\
\text { geader }\end{array}$ & $\begin{array}{l}\text { Clinical data is well } \\
\text { computerized } \\
\text { Clustering the diagnoses } \\
\text { into categories to predict } \\
\text { the future use of health } \\
\text { services. } \\
\text { Outputs from many risk } \\
\text { adjustment programs can } \\
\text { be collapsed into the } \\
\text { fewer } \\
\text { categories diagnostic }\end{array}$ & & $\begin{array}{l}\text { Prevent bealth care } \\
\text { providers to compote in } \\
\text { attracting bealthy patients } \\
\text { who are unlikely to take } \\
\text { advantage of their health } \\
\text { services. }\end{array}$ \\
\hline
\end{tabular}

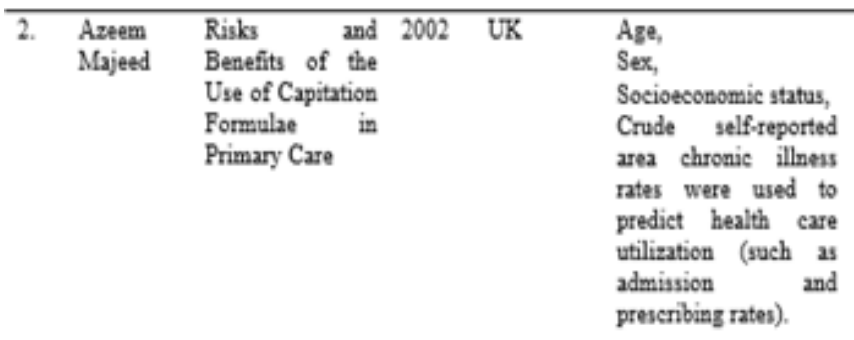

The models generally use a There are three key issues crude ecological measure of that need to be considered bealth status derived from the when evaluating the decennial census of the effectiveness of capitationpopulation based formulae: predict The measures of healtheare the correct share, effect in utilization-particularly hospital which doctors practice admission rates - are derived medicine, and beneficial from data that are known to effect.

contain errors.

The statistical models used to

derive capitation formulat afe

also complex and are not well

understood by most doctors or

health service managers

\begin{tabular}{|c|c|c|c|c|c|c|c|c|}
\hline & & & & US & $\begin{array}{l}\text { Age, } \\
\text { Sex, } \\
\text { Individual patients' } \\
\text { disease patterns and } \\
\text { bealtheare experiences }\end{array}$ & $\begin{array}{l}\text { Set a target date for } \\
\text { linking capitation } \\
\text { payments to the health } \\
\text { status of Medicare } \\
\text { beneficiaries. } \\
\text { The risk adjustment } \\
\text { models are a great step } \\
\text { forward in reducing the } \\
\text { financial incentives for } \\
\text { health plans to enroll } \\
\text { bealthy people }\end{array}$ & & \\
\hline 3. & $\begin{array}{l}\text { Anders } \\
\text { Anell, } \\
\text { Margareta } \\
\text { Dackehag, } \\
\text { Jens } \\
\text { Dietrichso } \\
\text { n }\end{array}$ & $\begin{array}{l}\text { Does Risk- } \\
\text { Adjusted } \\
\text { Payment } \\
\text { Influence } \\
\text { Primary Care } \\
\text { Providers' } \\
\text { Decision on } \\
\text { Where to Set Up } \\
\text { Practices? }\end{array}$ & 2016 & Sweden & $\begin{array}{l}\text { The major county used } \\
\text { Care Need Index } \\
\text { (CNI) and there are } \\
\text { other counties use } \\
\text { Adjusted Clinical } \\
\text { Groups (ACG) or } \\
\text { combination }\end{array}$ & $\begin{array}{l}\text { Increasing the number of } \\
\text { primary cares in areas } \\
\text { with } \\
\text { socioeconomic lower } \\
\text { demography } \\
\text { provides incentives for } \\
\text { primary care in locating } \\
\text { and creating the same } \\
\text { supply of primary care. }\end{array}$ & & \\
\hline 4. & $\begin{array}{l}\text { Lya M. } \\
\text { Sibley, } \\
\text { Richard } \\
\text { H. Glazier }\end{array}$ & $\begin{array}{l}\text { Evaluation of the } \\
\text { equity of age- } \\
\text { sex-adjusted } \\
\text { primary care } \\
\text { capitation } \\
\text { payments in } \\
\text { Ontario, Canada }\end{array}$ & 2012 & Canada & $\begin{array}{l}\text { Age and rex } \\
\text { comparing } \\
\text { capitation } \\
\text { compensation level } \\
\text { index with the } \\
\text { expected use of health } \\
\text { care rescurces relative } \\
\text { to socioeconomic } \\
\text { status (SES) }\end{array}$ & $\begin{array}{l}\text { Explains the age and } \\
\text { gender variables in } \\
\text { capitation in reflecting } \\
\text { the bealth care needs of } \\
\text { patients at all levels of } \\
\text { socioeconomic status by } \\
\text { comparing the capitation } \\
\text { compensation level index } \\
\text { adjusted for age Ontario } \\
\text { with the expected use of } \\
\text { health care resources } \\
\text { relative to socioeconomic } \\
\text { status (SES) }\end{array}$ & $\begin{array}{l}\text { This payment structure is that it } \\
\text { may be able to provide } \\
\text { incentives for risk selection, } \\
\text { usually referred to as cream- } \\
\text { skimming, which is the practice } \\
\text { of enrolling individuals who are } \\
\text { expected to use below average } \\
\text { levels of bealth care while } \\
\text { discouraging or rejecting the } \\
\text { expected individual enrollment } \\
\text { using above-average levels of } \\
\text { health care }\end{array}$ & $\begin{array}{l}\text { When using an ecological } \\
\text { proxy of socio-economic } \\
\text { status there is the } \\
\text { possibility } \\
\text { misclassifying individuals } \\
\text { to the wrong category. } \\
\text { However, it has been } \\
\text { shown that the } \\
\text { measurement of the } \\
\text { regional level of socio- } \\
\text { economic status typically } \\
\text { underentimates differesces } \\
\text { in inequality }\end{array}$ \\
\hline
\end{tabular}


conditions between women and men. Women have a higher risk because of the process of pregnancy, childbirth and breastfeeding (Ursila dan Iljanto, 2014). Research conducted by Wihono also found that women have 2.902 times greater opportunities in the utilization of Jamkesda compared with men (Wahono, 2011).

\section{Adoption of risk adjustment capitation payment system for Indonesia}

Based on risk adjustment conducted in UK and USA using age and gender as the basis of calculation of risk adjustment added with diagnosis factor, mortality and socioeconomic. Indonesia may initiate the use of risk adjustment based on the distribution of age and sex to participants enrolled in primary care as both factors are fundamental to the utilization of health services. Then Indonesia can develop risk adjustment based on diagnosis and socioeconomic to create more fair and accurate capitation rates for primary care. With the enactment of risk adjustments in the capitation payment system, it is hoped that each primary care will obtain a fair amount of capitation and be in line with the service needs and it is also expected to increase the quality control and cost control efforts of BPJS-Health.

Risk adjustment based on diagnostic factor in Indonesia can be supported by Sistem Informasi Kesehatan Daerah (SIKDA) through the application of SIKDA Generic at the primary care. The application of SIKDA Generic is the application of the National Standardized Health Information System to improve the availability and quality of health information and management data through the utilization of information and communication technology. The application of SIKDA Generic supports primary care to store all patient medical history (medical records) online, thus enabling primary care to know the health status of the community in its region in real time.

Based on the implementation risk adjustment capitation in Canada and Sweden, Indonesia can develop risk adjustment based on socioeconomic factor, considering the socioeconomic inequality in Indonesia is still high. Population distribution, income level, health and education status that is not evenly distribute are still importance issue to be resolved. Based on data from Central Bureau of Statistics in 2016, there are 7 million unemployed and 28.1 million poor people or 10.86 percent of the total population (Central Bureau of Statistics, 2016). People with low socioeconomic tend to increase morbidity and have a life expectancy of less than seven years, this may affect the utilization of health services, especially primary care. Risk adjustment based on socioeconomic factor in addition to age and sex can be a feasible way to achieve access equity, maximal utilization and cost efficiency of health service.

\section{Conclusion}

UK and USA use age and gender as the basis of calculation of risk adjustment added with diagnosis factor, mortality, and socio-economy. Canada use age and sex comparing -based capitation compensation level index with the expected use of health care resources relative to socioeconomic status (SES) and Sweden use Care Need Index (CNI). Indonesia may initiate the use of risk adjustment based on the distribution of age and sex to participants enrolled in primary care as both factors are fundamental to the utilization of health services. Furthermore, Indonesia can develop risk adjustment by using diagnosis and socioeconomics to produce a more accurate capitation payment system.

\section{Acknowlegment}

The authors would like to express our very great appreciation to Prof DR. Dr. Adik Wibowo MPH for her valuable and constructive suggestions during the planning and development of this manuscript. Her willingness to give her time so generously has been very much appreciated. We would also like to thank Septiara Putri S.K.M., M.P.H for her advice and assistance in keeping our progress on schedule. Our grateful thanks are also extended to Fikri Wijaya S.Sos for his help in manuscript preparation.

\section{Reference}

Anell, A., Dackehag, M. and Dietrichson, J. 2016. "Does Risk-Adjusted Payment Influence Primary Care Providers Decision on Where to Set Up Practices ?" BMC Health Services Research, (October), page. $1-12$.

Central Bureau of Statistics. 2016. Jumlah Pengangguran Indonesia 2016 Capai 7,02 Juta Orang. Jakarta.

Ikatan Dokter Indonesia. 2014. Panduan Praktik Klinis Bagi Dokter Di Fasilitas Pelayanan Kesehatan Primer. doi: 10.1017/CBO9781107415324.004.

Institute of Medicine (US) Committee on the Future of Primary Care. 1996. Primary Care: Ameri- 
ca's Health in a New Era. Diedit oleh K. L. K. et al Donaldson, MS; Yord. Washington DC: National Academies Press (US).

Kurnia, A. N. and Nurwahyuni, A. 2015. "Analisis Perhitungan Kapitasi pada Fasilitas Kesehatan Tingkat Pertama yang Bekerja Sama dengan BPJS Kesehatan KCU Kota Bogor Tahun 2015," Jurnal Ekonomi Kesehatan Indonesia, 2, page. 24-31.

Langenbrunner, J. C., Cashin, C. and Dougherty, S. O. 2009. "What, How, and Who: An Introduction to Provider Payment Systems," in How-To Manuals. Washington DC: The International Bank for Reconstruction and Development The World Bank, page. 4.

Majeed, A. 2002. "Risks and benefits of the use of capitation formulae in primary care," Disease Management and Health Outcomes, 10(4), hal. 215-220. doi: 10.2165/00115677-200210040-00002.

Majeed, A., Bindman, A. B. and Weiner, J. P. 2001 "Use of risk adjustment in setting budgets and measuring performance in primary care I: how it works," Bmj, 323(7313), hal. 604-607. Tersedia pada: http://www.bmj.com/ content/323/7313/604. extract.

Minister of Health of the Republic. 2013. Regulation of the Minister of Health of the Republic of Indonesia Number 69 Year 2013. Indonesia.

Nugraha, P. 2016. KPK Temukan 4 Kelemahan Pen- gelolaan Dana Kapitasi. 7 May 2018. https://www. kpk.go.id/id/berita/siaran-pers/2440-kpk-temukan-4-kelemahan-pengelolaan-dana-kapitasi.

Sibley, L. M. and Glazier, R. H. 2012 "Evaluation of the equity of age-sex adjusted primary care capitation payments in Ontario, Canada," Health Policy. Elsevier Ireland Ltd, 104(2), page. 186-192. doi: 10.1016/j.healthpol.2011.10.008.

Susilo, M. N. H. 2018. Rp 3,02 Triliun Dana Kapitasi Jaminan Kesehatan Nasional Menumpuk di Puskesmas.

Telykov, A. 2001. Guide to Prospective Capitation with Illustrations from Latin America," Health Sector Reform Initiative. [cited 2018 May 7]. Available from: http://new.paho.org/hq/dmdocuments/2010/51-Guide_Prospective_Capitation _Illustrations_from_LA.pdf.

Thabrany, H. 2005. Pendanaan kesehatan dan alternatif mobilisasi dana kesehatan di Indonesia. Jakarta: Raja Grafindo Persada.

Ursila, A. and Iljanto, S. 2014. Gambaran Utilisasi Pelayanan Kesehatan Di Puskesmas Kabupaten Bogor Di Era JKN Tahun 2014. Universitas Indonesia.

Wahono, I. 2011. Hubungan Determinan Individu Terhadap Utilisasi Pelayanan Kesehatan Jamkesda Puskesmas Tumbang Talaken, Kecamatan Manuhing, Kabupaten Gunung Mas Tahun 2011. Universitas Indonesia. 